\title{
MATURITY INDEXES FOR 'KUMAGAI' AND 'PALUMA' GUAVAS'
}

\author{
FLAVIA CRISTINA CAVALINI ${ }^{2}$, ANGELO PEDRO JACOMINO³, MICHELE ANTONIO LOCHOSKI ${ }^{4}$, \\ RICARDO ALFREDO KLUGE5, EDWIN MOISÉS MARCOS ORTEGA ${ }^{6}$
}

\begin{abstract}
Harvest time is one of the main factors related to guava fruit postharvest losses. It is subjectively determined by fruit size and skin color, without any consensual standardization among the growers. The use of maturity indexes enables growers to know the ideal harvest time according to each market situation. The objective of this work was to determine the maturity indexes to identify the harvest time for guava fruit cv. Kumagai and Paluma. Skin color, fruit firmness, soluble solids, titratable acidity, ratio and ascorbic acid were analyzed. The most adequate maturity indexes for 'Kumagai' guava fruit were skin color and pulp firmness, while for 'Paluma' guava fruit, the best indexes were skin color, pulp firmness, titratable acidity and ratio.
\end{abstract}

Index terms: postharvest; Psidium guajava; harvest maturity; firmness.

\section{ÍNDICES DE MATURIDADE PARA GOIABEIRAS 'KUMAGAI' E 'PALUMA'}

RESUMO - O ponto de colheita é um dos principais fatores de perda pós-colheita e, em goiaba, este é determinado de maneira subjetiva através da coloração externa e tamanho do fruto, não havendo uma padronização consensual entre os produtores. A utilização de índices de maturação permite que se conheça o ponto de colheita ideal para cada situação mercadológica. Este trabalho objetivou determinar tais índices que permitam identificar o ponto de colheita em goiabas 'Kumagai' e 'Paluma', em cinco estádios de maturação. Avaliaram-se cor da casca, firmeza, teor de sólidos solúveis, acidez titulável, ratio e teor de ácido ascórbico. Os índices de maturação mais adequados para 'Kumagai’ foram cor da casca e firmeza da polpa, e para 'Paluma', foram cor da casca, firmeza da polpa, acidez titulável e relação sólidos solúveis/acidez titulável.

Termos para indexação: pós-colheita; Psidium guajava, ponto de colheita, firmeza de polpa.

\section{INTRODUCTION}

Guava tree belongs to the Myrtaceae family. It is native of Tropical America, and is grown in Brazil from Rio Grande do Sul State up to Maranhão State, with São Paulo State standing out as the higher producer (Pereira, 1995).

Commercial orchards aiming at fruit production for fresh consumption require special management techniques, such as pruning and irrigation, besides fruit thinning and bagging. The normal guava production season in São Paulo State ranges from January to March. However, using pruning and irrigation systems, the production season is extended throughout the whole year. Guava tree blooms approximately 2 months after pruning and fruit can be harvested from 3 to 5 months after blooming, depending on the season of the year (Pereira, 1995).

The harvest time is an important factor related to postharvest losses of fruits and vegetables. For guavas, the harvest time is based in subjective evaluations as fruit size, skin color and "hand firmness", which may vary for the same location according to the cultivar, time of the year, plant age and management procedures (Piza Jr. \& Kavati, 1994).

There is neither standardization nor consensus as to the ideal ripening stage for harvesting guavas. Fruit are generally harvested when the pulp is still firm and the skin color starts changing from dark to light green or to a yellowish color (Manica et al., 2000).

In order to establish the correct harvest period, it is necessary to determine precisely the fruit ripening stage by using maturity indexes. Such indexes include physical or chemical measurements that change perceptibly along fruit ripening. Its use enables the production of good quality fruits regarding sensory characteristics, besides guaranteeing suitable behavior during storage (Kluge et al., 2002).

The purpose of this work was to determine the reliable maturity index to establish the harvest time for guava fruits cultivars 'Kumagai' and 'Paluma'.

\section{MATERIAL AND METHODS}

Guavas (Psidium guajava L.) cultivar Kumagai were harvested from commercial orchards in Campinas (22 $52^{\prime} \mathrm{S}, 47^{\circ} 02^{\prime} \mathrm{W}$, $685 \mathrm{~m}$ ) on June and Paluma were harvested from commercial orchards in Vista Alegre do Alto (21 $10^{\prime}$ S, 48 38'W, 700m) on March, São Paulo State, Brazil. Guavas were harvested at five ripening stages, based on the fruit skin color, according to color scale (Table 1) and placed in plastic boxes lined with plastic foam in order to avoid mechanical injuries and immediately taken to the Post Harvest Laboratory of the Crop Production Department at "Escola Superior de Agricultura Luiz de Queiroz" (ESALQ/USP).

TABLE 1 - Skin color scale for 'Kumagai' and 'Paluma' guava.

\begin{tabular}{lll}
\hline Stages & Kumagai & Paluma \\
\hline 1 & Dark green & Dark green \\
2 & Green & Light green \\
3 & Light green & Yellowish green \\
4 & Yellowish green & Greenish yellow \\
5 & Light yellow & Yellow \\
\hline
\end{tabular}

In the laboratory fruits were analyzed concerning to: a) Skin color: determined with a Minolta colorimeter, CR-300, by means of two readings per fruit on opposite sides along the fruit equatorial region. Results were expressed in hue color angle $\left(\mathrm{h}^{\circ}\right)$, according to McGuirre (1992); b) Firmness: determined with a digital penetrometer by carrying out two reading per fruit on opposite sides along the fruit equatorial region. Fruit skin was removed at the reading spot to ensure that pulp firmness, rather than skin firmness, was assessed. Results were expressed in Newton; c) Soluble solids (SS): determined by direct reading of a homogenized pulp drop in a refractometer Atago Pallete 101. Results were expressed in ${ }^{\circ}$ Brix; d) Titratable acidity (TA): determined by titration with $\mathrm{NaOH} 0.1 \mathrm{~N}$, with results expressed in percentage of citric acid; e) Ratio: determined by the relation between

\footnotetext{
${ }^{1}$ (Trabalho 192-2005). Recebido: 24-11-2005. Aceito para publicação: 30-06-2006. (19) 3429-4354, fccavali@yahoo.com, financed by Capes.

${ }^{3}$ Professor Dr, ESALQ-USP, Crop Production Department, (19) 3429-4190, jacomino@esalq.usp.br.

${ }^{4}$ Undergraduate student of Food Science, ESALQ-USP.

${ }^{5}$ Professor Dr, ESALQ-USP, Biological Sciences Department, (19) 3429-4136, rakluge@ esalq.usp.br.

${ }^{6}$ Professor Dr, ESALQ-USP, Exact Sciences Department, (19) 3429-4145, edwin@esalq.usp.br.
}

${ }^{2}$ Agronomist, MSc, Escola Superior de Agricultura "Luiz de Queiroz" (ESALQ-USP), Biologial Sciences Department, CP 09, CEP 13418-900. Piracicaba, SP, 
TABLE 2 - Physicochemical characteristics of 'Kumagai' and 'Paluma' guava at five ripening stages.

\begin{tabular}{|c|c|c|c|c|c|c|}
\hline \multirow{2}{*}{ Physicochemical characteristics } & \multicolumn{6}{|c|}{ Ripening stages at harvest time $^{1}$} \\
\hline & 1 & 2 & 3 & 4 & 5 & CV (\%) \\
\hline \multicolumn{7}{|l|}{ 'Kumagai' } \\
\hline Firmness (N) & $106.05 \mathrm{a}$ & $85.52 \mathrm{~b}$ & $82.35 \mathrm{bc}$ & $72.30 \mathrm{bc}$ & $65.41 \mathrm{c}$ & 23.8 \\
\hline Skin color $\left(\mathrm{h}^{0}\right)$ & $118.27 \mathrm{a}$ & $117.08 \mathrm{a}$ & $115.16 \mathrm{~b}$ & $113.02 \mathrm{c}$ & $111.05 \mathrm{~d}$ & 1.1 \\
\hline Ascorbic acid (mg.100g $\left.{ }^{-1}\right)$ & $103.28 \mathrm{c}$ & $107.87 \mathrm{bc}$ & $105.38 \mathrm{c}$ & $112.21 \mathrm{~b}$ & $128.36 \mathrm{a}$ & 6.3 \\
\hline Soluble Solids ( $\left.{ }^{\circ} \mathrm{Brix}\right)$ & $6.0 \mathrm{c}$ & $6.2 \mathrm{bc}$ & $6.7 \mathrm{a}$ & $6.4 \mathrm{ab}$ & $6.6 \mathrm{a}$ & 6.6 \\
\hline Titratable Acidity (\%) & $0.59 \mathrm{a}$ & $0.53 \mathrm{~b}$ & $0.57 \mathrm{ab}$ & $0.56 \mathrm{ab}$ & $0.56 \mathrm{ab}$ & 7,3 \\
\hline Ratio & 10.10 & 11.62 & 11.93 & 11.46 & 11.76 & 9.2 \\
\hline \multicolumn{7}{|l|}{ 'Paluma' } \\
\hline Firmness $(\mathrm{N})$ & $132.50 \mathrm{a}$ & $74.74 \mathrm{~b}$ & $48.89 \mathrm{c}$ & $28.99 \mathrm{~d}$ & $20.06 \mathrm{~d}$ & 29.0 \\
\hline Skin color $\left({ }^{\circ} \mathrm{h}\right)$ & $114.42 \mathrm{a}$ & $108.05 \mathrm{~b}$ & $102.39 \mathrm{c}$ & $95.86 \mathrm{~d}$ & $89.76 \mathrm{e}$ & 2.9 \\
\hline Ascorbic acid (mg.100g ${ }^{-1}$ ) & $62.80 \mathrm{~d}$ & $72.02 \mathrm{bc}$ & $70.37 \mathrm{c}$ & $75.40 \mathrm{~b}$ & $84.94 \mathrm{a}$ & 6.0 \\
\hline Soluble Solids ( ${ }^{\circ}$ Brix) & $7.7 \mathrm{~b}$ & $7.5 \mathrm{~b}$ & $7.6 \mathrm{~b}$ & $7.5 \mathrm{~b}$ & $8.3 \mathrm{a}$ & 5.5 \\
\hline Titratable Acidity (\%) & $0.78 \mathrm{a}$ & $0.66 \mathrm{~b}$ & $0.61 \mathrm{c}$ & $0.53 \mathrm{~d}$ & $0.47 \mathrm{e}$ & 4.9 \\
\hline Ratio & 9.88 & 11.42 & 12.60 & 14.20 & 17.66 & 7.4 \\
\hline
\end{tabular}

Means followed by the same letters in the lines do not differ by Tukey test (Pd"0.05).

${ }^{1}$ 'Kumagai': 1- dark green; 2- green; 3- light green; 4- yellowish green; 5- light yellow. 'Paluma': 1- dark green; 2- light green; 3- yellowish green; 4- greenish yellow; 5- yellow.

the soluble solids amount and the titratable acidity; f) Ascorbic acid: determined by titration (AOAC, 1995), with results expressed in mg of ascorbic acid by $100 \mathrm{~g}$ of pulp.

A completely randomized experimental design was used, with 15 fruit for each ripening stage and cultivars. Five replications of 3 fruit were used, totalizing 150 fruits $(5$ stages $x 2$ cultivars $x 5$ replications $\mathrm{x} 3$ fruits). Results were submitted to variance analysis (ANOVA) and means were compared by Tukey test $(\mathrm{P} \leq 0.05)$. In order to study the existing correlations among the physicochemical variables at the different ripening stages, analysis of Pearson's correlation was made and in order to determine which variable contributes the most to discriminate a ripening stage, it was applied discriminate analysis by using SPSS Professional Statistics.

\section{RESULTS AND DISCUSSION}

The characterization of different ripening stages should be based on a set of values, or maturity indexes, representing the fruit development stage, associating each stage to a quality sensory. The table 2 shows the physicochemical characteristics of 'Kumagai' and 'Paluma' guava fruit harvested at five ripening stages.

'Paluma' fruit showed larger variation in firmness according to the ripening stages than the observed in 'Kumagai' fruit. Thus, 'Paluma' fruit showed raised loss of firmness due the ripening, while in the 'Kumagai' fruit this could be not observed.

Hue color angle $\left(\mathrm{h}^{\circ}\right)$ may vary from $0^{\circ}$ to $360^{\circ}$, with $0^{\circ}, 90^{\circ}$, $180^{\circ}$ and $270^{\circ}$ corresponding to red, yellow, green and blue colors, respectively. In guava, the hue color angle significantly expresses the changes in skin color. Unripe guavas show higher hue color angle than the ripe fruit.

The use of the skin color as a maturity index showed to be viable, as it enabled the differentiation among the ripening stages, with unripe guavas presenting higher hue color angle than ripe ones. The results obtained are in accordance with Azzolini et al. (2004a) that has considered skin color as the best index to determine 'Pedro Sato' guava maturation index, and also in accordance with Mercado-Silva et al. (1998), which founded similar results for guava 'Média China'. For 'Kumagai' guava fruit, no difference was observed between stages 1 and 2, while for 'Paluma' guava all stages showed differences from one another. Skin color shows low variation coefficient when compared to other variables, yielding more reliable results and is easy to assess during harvest time, as its determination does not harm fruits.

Ascorbic acid was higher in fruits harvested at a more advanced ripening stage. For 'Kumagai' fruit, the ascorbic acid at stage 5 was $128.36 \mathrm{mg} .100 \mathrm{~g}^{-1}$, while in the other stages ascorbic acid varied from 103.28 to $112.21 \mathrm{mg} .100 \mathrm{~g}^{-1}$. 'Paluma' fruit showed larger difference in ascorbic acid among stages, varying from 84.94 to 62.80 mg. $100 \mathrm{~g}^{-1}$. The increase of ascorbic acid due to ripening was also observed by Jacomino et al. (2001) in 'Kumagai' guava fruits. However, Azzolini et al. (2004b) have observed significant differences in ascorbic acid amount in 'Pedro Sato' guava fruit harvested in several ripening stages.

No differences were observed among the ripening stages in both guava cultivars when the SS was considered. It shows that this variable is not a good index to characterize the ripening stages. In

TABLE 3 - Correlation coefficients (r) for the physicochemical variables of 'Kumagai' and 'Paluma' guavas harvested at five ripening stages'

\begin{tabular}{|c|c|c|c|c|}
\hline & Titratable Acidity (\%) & Firmness (N) & Soluble Solids ( ${ }^{0}$ Brix) & Ascorbic acid (mg.100g $\left.{ }^{-1}\right)$ \\
\hline 'Kumagai' & & & & \\
\hline Skin color $\left({ }^{\circ} \mathrm{h}\right)$ & $0.068^{\mathrm{NS}}$ & $0.605^{* *}$ & $-0.411^{* *}$ & $-0.641^{* *}$ \\
\hline Titrable Acidity (\%) & - & $0.333^{* *}$ & $0.051^{\mathrm{NS}}$ & $-0.074^{\mathrm{NS}}$ \\
\hline Firmness $(\mathrm{N})$ & & 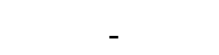 & $-0.224^{\mathrm{NS}}$ & $-0.463^{* *}$ \\
\hline $\begin{array}{l}\text { Soluble Solids ('Brix) } \\
\text { 'Paluma' }\end{array}$ & & & - & $0.278^{*}$ \\
\hline Skin color $\left({ }^{\circ} \mathrm{h}\right)$ & $0.937^{* *}$ & $0.879^{* *}$ & $-0.350^{* *}$ & $-0.755^{* *}$ \\
\hline Titrable Acidity (\%) & - & $0.898^{* *}$ & $-0.236^{*}$ & $-0.764^{* *}$ \\
\hline Firmness $(\mathrm{N})$ & & - & $-0.144^{\mathrm{NS}}$ & $-0.677^{* *}$ \\
\hline Soluble Solids ( ${ }^{\circ}$ Brix $)$ & & & - & $0.236^{*}$ \\
\hline
\end{tabular}

'Kumagai': 1- dark green; 2- green; 3- light green; 4- yellowish green; 5- light yellow. 'Paluma': 1- dark green; 2- light green; 3- yellowish green; 4- greenish yellow; 5- yellow.

Number of points considered in the correlation analysis $=75$ points

*,*, NS, Correlation significant at Pd" $0.01,0.05$ or non significant, respectively. 
'Kumagai' guava, SS varied from 6.0 to $6.7^{\circ}$ Brix while in 'Paluma' guava fruit values varied from 7.5 to $8.3^{\circ}$ Brix. Such values are lower than those found by Lima et al. (2002) for 'Banahas', 'Lucknow 49' and 'Paluma' guava in the region of sub-medium São Francisco, Brazil. However, these results were similar to those observed by Bassetto et al. (2002) guava and higher from those verified by Azzolini et al. (2004a) with 'Pedro Sato' guava.

In relation to TA it was no differences observed among the ripening stages in 'Kumagai'. For this cultivar, values varied from 0.53 to $0.59 \%$ of citric acid. For the cultivar Paluma, fruit harvested at the less advanced ripening stages showed higher acidity if compared to those harvested at the more advanced ripening stage. TA enabled the differentiation among most stages, varying from $0.78 \%$ in less ripe fruits, to $0.47 \%$ in more ripe fruits. The results obtained are similar from the observed by Azzolini et al. (2004a) and by Pivetta et al. (1992) for 'Pedro Sato' and 'Paluma' guava, respectively.

The ratio ranged from 10.10 to 11.93 for 'Kumagai' guava, showing no differences among the five stages. However, for the cultivar Paluma, the ratio showed a good differentiation among stages and could be used as a maturity index for red pulp guava fruit. Some authors, such as Chitarra (1981) and Azzolini et al. (2004a), suggests that this variable can be used as a maturity index for guava fruit, but it is important to notice that it cannot be used for all guava cultivars.

The use of more than one variable to characterize a specific ripening stage results in greater precision when classifying fruits and evidences the correlation among the maturity indexes. It also allows the study of one variable as a function of another, eliminating the need of a destructive analysis by correlating some characteristics to others determined by non-destructive analysis.

The skin color index in 'Kumagai' guava showed a highly significant correlation with pulp firmness, SS and ascorbic acid in both studied cultivars. In 'Paluma' guava skin color was correlated also to the TA (Table 3).

Skin color can be considered as a good maturity harvest index, due this index showed the majority of the correlated index in both cultivars. The discriminate analysis showed that for 'Kumagai' guava only the pulp firmness did not contribute to discriminate the ripening stages, since it was not possible to determine the discriminate functions coefficients for this variable. However, for 'Paluma' all the variables showed coefficients for the discriminate functions. This
TABLE 4 - Analyzed fruits classification

\begin{tabular}{lcccccc}
\hline Maturation Stages & \multicolumn{7}{c}{ Predicted Group Membership } & \multirow{2}{*}{ Total } \\
at Harvest Time $^{1}$ & $\mathbf{1}$ & $\mathbf{2}$ & $\mathbf{3}$ & $\mathbf{4}$ & $\mathbf{5}$ & \\
\hline 'Kumagai' & & & & & & \\
$\mathbf{1}$ & 13 & 2 & 0 & 0 & 0 & 15 \\
$\mathbf{2}$ & 1 & 12 & 2 & 0 & 0 & 15 \\
$\mathbf{3}$ & 1 & 1 & 11 & 2 & 0 & 15 \\
$\mathbf{4}$ & 0 & 0 & 2 & 10 & 3 & 15 \\
$\mathbf{5}$ & 0 & 0 & 0 & 0 & 15 & 15 \\
'Paluma' & & & & & & \\
$\mathbf{1}$ & 15 & 0 & 0 & 0 & 0 & 15 \\
$\mathbf{2}$ & 0 & 13 & 2 & 0 & 0 & 15 \\
$\mathbf{3}$ & 0 & 1 & 14 & 0 & 0 & 15 \\
$\mathbf{4}$ & 0 & 0 & 0 & 15 & 0 & 15 \\
$\mathbf{5}$ & 0 & 0 & 0 & 0 & 15 & 15 \\
\hline
\end{tabular}

'Kumagai': 1- dark green; 2- green; 3- light green; 4- yellowish green; 5- light yellow. 'Paluma': 1- dark green; 2- light green; 3- yellowish green; 4- greenish yellow; 5- yellow.

means that all the variables had contributed to discriminate ripening stages.

In table 4 is possible to verify the data classification, where $81.3 \%$ and $96 \%$ of the data are classified adequately for 'Kumagai' and 'Paluma', respectively. This means that from the 75 evaluated fruit of 'Kumagai' guava, 14 do not belong from the stage where they are and for 'Paluma' only 3 of the 75 evaluated fruits they do not correspond to the attributed stage. In figure 1 is possible to observe the canonic distribution of these data, being shown that 'Paluma' guava presented better classification data than 'Kumagai'. In 'Paluma' guava the differences between ripening stage were more pronounced than the observed in 'Kumagai'guava. The SS and TA, those are normally important to define harvest time in several fruits, do not shown this for 'Kumagai' guava.

Skin color showed the best indicator to define the ripening stage for both studied cultivar. This subjective and non-destructive determination is easy to be detected by producers, however now a days there is no language standardization among them. A color table based in results obtained in this experiment could be useful. The correlations observed among the variables evaluated in this experiment can to differ in function of climatic condition, mainly time of the year and production area. These variations sources should be exploited in the next researches.

\section{'Kumagai'}

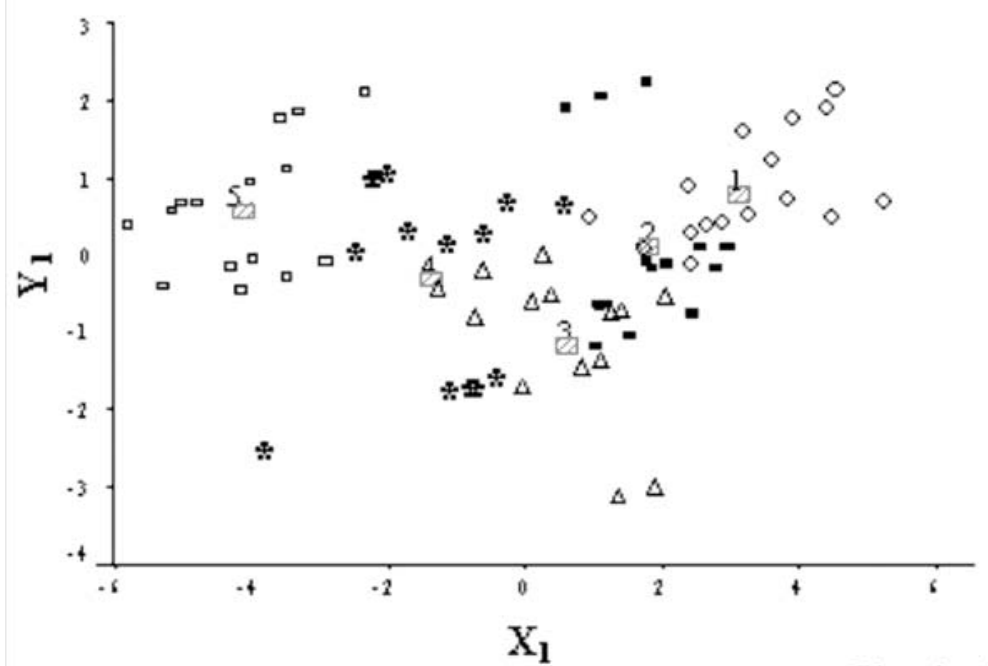

'Paluma'

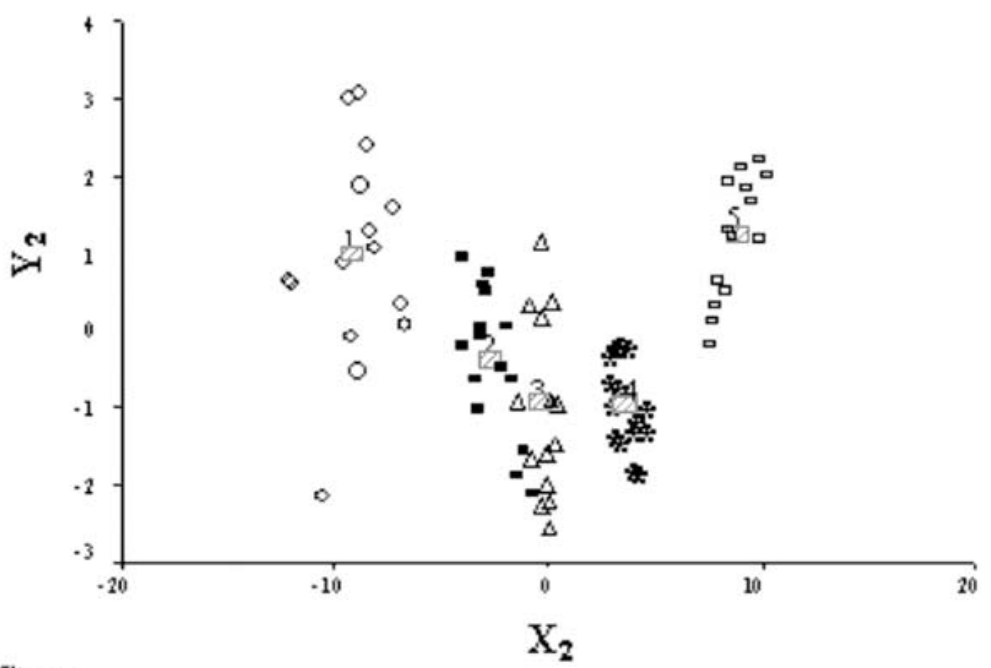

Ripening Stages

$$
\text { Group Centroids } \square=5 \text { * } 4 \quad \Delta \quad 3=2 \quad \begin{array}{llllllll}
2 & 0 & 1
\end{array}
$$

FIGURE 1 - Canonical discriminant function of 'Kumagai' and 'Paluma' guava. $\mathrm{X}_{1}, \mathrm{X}_{2}, \mathrm{Y}_{1}$ and $\mathrm{Y}_{2}$ are canonical discriminant functions. 


\section{CONCLUSION}

The maturity indexes that best differentiates the ripening stages in 'Kumagai' guava fruit is skin color, while in 'Paluma' guava are skin color, pulp firmness, titratable acidity and ratio.

\section{REFERENCES}

ASSOCIATION OF OFFICIAL ANALYTICAL CHEMISTS. Food composition, additives, natural contaminants, In: ASSOCIATION OF OFFICIAL ANALYTICAL CHEMISTS. Official methods of analysis of AOAC international. Washington: AOAC International, 1995. cap.37, p.1-23.

AZZOLINI, M.; JACOMINO, A. P.; BRON, I. U. Índices para avaliar qualidade pós-colheita de goiabas em diferentes estádios de maturação. Pesquisa Agropecuária Brasileira, Brasília, vol.39, no.2, p.139-145, fev. 2004 a.

AZZOLINI, M.; JACOMINO, A. P.; SPOTTO, M.H.F. Estádios de maturação e qualidade pós-colheita de goiabas 'Pedro Sato'. Revista Brasileira de Fruticultura, Jaboticabal, vol.26, no.1, p.2931, $2004 \mathrm{~b}$.

BASSETTO, E.; SESSO, T.M.; JACOMINO, A.P.; KLUGE, R.A. Efeito de 1-MCP e Prochloraz na conservação de goiabas 'Pedro Sato'. Revista Iberoamericana de Tecnologia Postcosecha, México, v.4, n.2, p.122-127, 2002.

CHITARRA, M.I.F.: CHITARRA, A.B. CARVALHO, V.D. Algumas características dos frutos de duas cultivares de goiabeira (Pisidium guajava L) em fase de maturação. In: CONGRESSO BRASILEIRO DE FRUTICULTURA, 6.. 1981. Recife. Anais... Recife: SBF, 1981. v.2, p.771-780.

JACOMINO, A. P.; SIGRIST, J.M.M.; SARANTÓPOULOS, C.I.G. DE L.; MINAMI, K.; KLUGE, R.A. Embalagens para conservação refrigerada de goiabas. Revista Brasileira de Fruticultura, Jaboticabal, v.23, n.1, p.50-54, 2001.

JOHNSON, R.A.; WICHERN, D.N. Applied multivariate statistical analysis. Englewood Cliffs: Prentice Hall, 1982. 607 p.

KLUGE, R. A.; NACHTIGAL, J.C.; FACHINELLO, J.C.; BILHALVA, A.B. Fisiologia e manejo pós-colheita de frutas de clima temperado. 2. ed. Pelotas: UFPEL, 2002. 163p.

LIMA, M. A. C. de; ASSIS, J. S. de; GONZAGA NETO, L. Caracterização dos frutos de goiabeira e seleção de cultivares na Região do Submédio São Francisco. Revista Brasileira de Fruticultura, Jaboticabal, v. 24, n.1, p.273-276, 2002.

MANICA, I.; ICUMA, I.M.; JUNQUEIRA, N.T.V.; SALVADOR, J.O.; MOREIRA, A.; MALAVOLTA, E. Fruticultura tropical: goiaba. Porto Alegre: Cinco Continentes, 2000. cap.6, 373p.

MARDIA, K.V.; KENT, J.T.; BIBBY, J.M. Multivariate analysis. New York: Academic Press, 1994. 521 p.

McGUIRE, R.G. Reporting of objective color measurements. HortScience, Alexandria, v.27, n.12, p.1254-1255, 1992.

MERCADO-SILVA,E.; BAUTISTA,P.B.; GARCIA-VELASCO,M.A. Fruit development, harvest index ripening changes of guavas produced in central Mexico. Postharvest Biology and Technology, Amsterdan, v.13, n.2, p.143-150, 1998.

PEREIRA, F.M. Cultura da goiabeira. Jaboticabal: Funep, 1995. 47p.

PIVETTA, K.F.L., DURIGAN, J.F.; PEREIRA, F.M. Avaliação da conservação pós-colheita, em condições ambientais, de frutos de goiabeira (Psidium guajava $L$.) colhidos em diferentes estádios de maturação. Revista Brasileira de Fruticultura, Jaboticabal, v.14, n.3, p.236-239, 1992.

PIZA Jr, C.T.; KAVATI, R. A cultura da goiabeira de mesa. Campinas: CATI, 1994. 28p. (Boletim Técnico, 219).

SPSS Professional Statistics version 8.2. Chicago. 